\title{
Influence of Irrigation Scheduling with Levels and Times of Nitrogen Application on Root Growth of Aerobic Rice
}

\section{Murugesan Mohana Keerthi ${ }^{1}$, Rajagopalan Babu' ${ }^{2}$, Nagalingam Somasundaram Venkataraman ${ }^{1}$, Peyandi Paraman Mahendran ${ }^{3}$}

\footnotetext{
${ }^{1}$ Department of Agronomy, Agricultural College and Research Institute, Tamil Nadu Agricultural University, Madurai, India ${ }^{2}$ Department of Farm Management, Agricultural College and Research Institute, Tamil Nadu Agricultural University, Madurai, India

${ }^{3}$ Department of Soils and Environment, Agricultural College and Research Institute, Tamil Nadu Agricultural University, Madurai, India
}

Email: *mmkeerthi@gmail.com

How to cite this paper: Keerthi, M.M., Babu, R., Venkataraman, N.S. and Mahendran, P.P. (2018) Influence of Irrigation Scheduling with Levels and Times of Nitrogen Application on Root Growth of Aerobic Rice. American Journal of Plant Sciences, 9, 2297-2305.

https://doi.org/10.4236/ajps.2018.911166

Received: October 8, 2018

Accepted: October 26, 2018

Published: October 29, 2018

Copyright (c) 2018 by authors and Scientific Research Publishing Inc. This work is licensed under the Creative Commons Attribution International License (CC BY 4.0).

http://creativecommons.org/licenses/by/4.0/

\section{(c) (i) Open Access}

\begin{abstract}
Aerobic rice is one of the alternative methods for saving water, energy, labour, time and reduced methane gas in rice production ecosystem. The field experimental trial was conducted during summer 2018 at Agricultural College and Research Institute, Madurai. Irrigation scheduling based on different IW/CPE (Irrigation Water/Cumulative Pan Evaporation) ratios and different doses along with various spilt applications of nitrogen were experimented. Results of field experiment indicated that irrigation scheduling at IW/CPE of 0.8 up to panicle initiation stage and thereafter IW/CPE of 1.0 up to dough stage recorded the highest root length of $13.0 \mathrm{~cm}$ at active tillering and 18.8 $\mathrm{cm}$ at flowering stage. But, irrigating the aerobic rice at IW/CPE of 1.0 up to panicle initiation stage and thereafter IW/CPE of 1.2 up to dough stage recorded the highest root volume $\left(16.9,27.1 \mathrm{cc} \cdot \mathrm{hill}^{-1}\right)$ and root dry weight (6.1, $\left.12.9 \mathrm{~g} \cdot \mathrm{hill}^{-1}\right)$ at active tillering and flowering stage. Application of nitrogen at $150 \mathrm{~kg} \cdot \mathrm{ha}^{-1}$ in 5 equal splits at 20,35, 50, 65 and 80 DAS (Days after sowing) recorded the highest root length of $13.5 \mathrm{~cm}$, root volume of $17.6 \mathrm{cc} \cdot \mathrm{hill}^{-1}$ and root dry weight of $6.4 \mathrm{~g} \cdot \mathrm{hill}^{-1}$ at active tillering stage and root length of 19.4 $\mathrm{cm}$, root volume of $27.6 \mathrm{cc} \cdot \mathrm{hill}^{-1}$ and root dry weight of $14.4 \mathrm{~g} \cdot \mathrm{hill}^{-1}$ at flowering stage. The interaction effect of irrigation and nitrogen significantly influenced the root growth. Irrigation at IW/CPE of 0.8 up to panicle initiation stage and thereafter IW/CPE of 1.0 up to dough stage along with $150 \mathrm{~kg} \mathrm{~N}$ $\mathrm{ha}^{-1}$ in 5 equal splits at 20,35,50,65 and 80 DAS significantly enhanced the root length $(15.7,23.6 \mathrm{~cm})$ at active tillering and flowering stage. However,
\end{abstract}


irrigation scheduling at IW/CPE of 1.0 up to panicle initiation stage and thereafter IW/CPE of 1.2 up to dough stage along with application of N 150 $\mathrm{kg} \cdot \mathrm{ha}^{-1}$ in 5 equal splits at 20,35, 50, 65 and 80 DAS registered the highest root volume $\left(20.3,32.8 \mathrm{cc} \cdot \mathrm{hill}^{-1}\right)$ and root dry weight $\left(8.3,16.4 \mathrm{~g} \cdot \mathrm{hill}^{-1}\right)$ at active tillering and flowering stage.

\section{Keywords}

Irrigation, IW/CPE Ratio, Nitrogen, Root Growth, Aerobic Rice

\section{Introduction}

Rice is the staple food for half of the world population and grown area is 158.5 million hectares with a production of 470.6 million tons and productivity of 4.43 $\mathrm{t} \cdot \mathrm{ha}^{-1}$. India is the second largest producer (103.5 million tons) of rice after China (145.7 million tons) [1]. However, additionally rice has to be produced at rate of 1.7 million tonnes per year to sustain the national food security [2]. In India, urbanization and rapid increases in population are gradually deteriorating the availability of water for agriculture. Groundwater tables have dropped on an average by 0.5 - 0.7 meter.year ${ }^{-1}$ in the Indian states of Karnataka, Maharashtra, Rajasthan, Punjab, Haryana, northern Gujarat and Tamil Nadu [3]. This forces the farmers to look in for alternative methods of irrigating rice crop for sustaining rice production. Aerobic rice is a water saving method of growing rice by direct seeding of high yielding varieties in un-puddled condition without standing water and irrigated similar to other upland cereal crops [4].

Proper scheduling of irrigation is needed for more efficient use of water and to increase the shoot and root growth, for increased yield [5]. In irrigation scheduling, climatological approach based on IW/CPE ratio has been found to be the most appropriate method. This approach integrates all the weather parameters that determine water use by the crop [6]. Normally, aerobic rice culture promotes lateral root branching and deep rooting compared to transplanted rice [7]. Rice plants grown under intermittent irrigation management had higher root activity under aerobic conditions [8]. Nitrogen fertilization should be balanced between maximizing yield and minimizing the risk of lodging in rice crop. Nitrogen fertilization with proper time of application is the major agronomic practice that affects the growth and yield of rice crop [9]. Application of nitrogen in splits according to crop requirement causes not only reduces the loss of nitrogen but also increased the nitrogen absorption by higher root growth [10]. In aerobic system, the dominant form of nitrogen is nitrate and relatively little ammonia volatilization is expected after nitrogen fertilizer application [11]. A major problem of irrigated rice systems is the increasing water scarcity. In fact, the water scarcity is threatening Asia's irrigated rice production system and rice is very sensitive to water stress and attempts to reduce water inputs may result in growth and yield reduction. The challenge is to develop novel technolo- 
gies and production to be maintained in the face of declining water availability. The response of root growth dynamics to irrigation managements is well understood in flood culture of rice cultivation. But in aerobic rice culture, the response of root growth to severe soil drying has been intensively studied [7]. However, information on potential of aerobic rice, suitable irrigation management is lacking in Indian continent. Next to water, nitrogen is the most important factor for rice production. The crop response to nitrogen application was observed up to $175 \mathrm{~kg} \cdot \mathrm{ha}^{-1}$ in aerobic rice [12]. However, such information is limited and there is a need to quantifying and optimizing the nitrogen doses at different growth stages. In addition, altering the split doses according to the crop requirement is also needed to be optimizing under aerobic rice cultivation with relation to root growth and activities. Hence, this experiment was conducted to study the influence of various irrigation scheduling and nitrogen levels and time of applications on root growth for aerobic rice.

\section{Materials and Methods}

\subsection{Experimental Site, Design and Selection of Cultivar}

Field experiment was conducted during the summer 2018 at Agricultural College and Research Institute, Madurai located at the southern agro climatic zone of Tamil Nadu, India. The experimental site is geographically located at $9^{\circ} 54^{\prime} \mathrm{N}$ latitude and $78^{\circ} 54^{\prime} \mathrm{E}$ longitude and at an altitude of $147 \mathrm{~m}$ above mean sea level. The field experiment was laid out in split plot design with three replications and variety ADT (R) 45 was used with a spacing of $20 \times 10 \mathrm{~cm}$. The population was maintained by gap filling and thinning. The soil of experimental site was sandy clay loam in texture. Irrigation water was measured through Parshall flume.

\subsection{Treatment Details}

Main plot: Irrigation scheduling

$\mathrm{I}_{1}$-IW/CPE 0.8 throughout the growth stage

$\mathrm{I}_{2}-\mathrm{IW} / \mathrm{CPE} 0.8$ up to panicle initiation stage and thereafter IW/CPE 1.0 up to dough stage

$\mathrm{I}_{3}-\mathrm{IW} / \mathrm{CPE} 0.8$ up to panicle initiation stage and thereafter IW/CPE 1.2 up to dough stage

$\mathrm{I}_{4}$-IW/CPE 1.0 throughout the growth stage

$\mathrm{I}_{5}$-IW/CPE 1.0 up to panicle initiation stage and thereafter IW/CPE 1.2 up to dough stage

(Note: IW/CPE-Irrigation Water/Cumulative Pan Evaporation)

Sub plot: Nitrogen management

$\mathrm{N}_{1}-100 \mathrm{~kg}$ N: 4 equal splits at 20, 40,60 and 80 DAS

$\mathrm{N}_{2}-100 \mathrm{~kg} \mathrm{~N}: 5$ equal splits at 20, 35, 50, 65 and 80 DAS

$\mathrm{N}_{3}-125 \mathrm{~kg} \mathrm{~N}: 4$ equal splits at 20,40,60 and 80 DAS

$\mathrm{N}_{4}-125 \mathrm{~kg} \mathrm{~N}$ : 5 equal splits at 20, 35, 50, 65 and 80 DAS

$\mathrm{N}_{5}-150 \mathrm{~kg} \mathrm{~N}: 4$ equal splits at 20,40,60 and 80 DAS 
$\mathrm{N}_{6}-150 \mathrm{~kg}$ N: 5 equal splits at 20, 35, 50, 65 and 80 DAS

(Note: N-Nitrogen, DAS-Days after sowing)

\subsection{Statistical Analysis}

The observed data on crop were statistically analysed by following the procedure for split plot design as described by Gomez and Gomez [13]. Analysis was done with the help of "AGRIS" software. Critical differences (C.D) were worked out at five per cent probability level to check the significance of treatment's mean. The treatment differences that were non-significant at five per cent were denoted as NS.

\subsection{Observations}

\subsubsection{Root Length}

The entire hill along with root intact with the soil was scooped carefully and washed in running water. The root length was measured from base to tip of the longest root and expressed in $\mathrm{cm}$.

\subsubsection{Root Volume}

The roots scooped along with the soil and washed in running water carefully. Root volume was found out by placing the root mass into a measuring cylinder containing a known volume of water. The increase in the water column was assessed and expressed as cc.hill ${ }^{-1}$.

\subsubsection{Root Dry Weight}

The sampled plant's root were collected, cleaned in running water and dried in hot air oven at $70^{\circ} \mathrm{C} \pm 20^{\circ} \mathrm{C}$ till it reached a constant weight and expressed as g.plant ${ }^{-1}$.

\section{Results and Discussion}

Irrigation scheduling of IW/CPE 0.8 up to panicle initiation and thereafter IW/CPE 1.0 up to dough stage $\left(I_{2}\right)$ recorded the highest root length $(13.0 \mathrm{~cm})$ at active tillering stage and $(18.8 \mathrm{~cm})$ at flowering stage (Table 1). Increased root length under lesser IW/CPE ratios may be an added advantage to combat stress under water limitation condition as reported earlier by Matsuo et al. [14] and Parthasarathi et al. [15]. However, significantly higher root volume (16.9, 27.1 cc.hill $\left.{ }^{-1}\right)$ and root dry weight $\left(6.1,12.9 \mathrm{~g} \cdot\right.$ hill $\left.^{-1}\right)$ at active tillering and flowering stage were recorded when irrigation at IW/CPE of 1.0 up to panicle initiation stage and thereafter IW/CPE of 1.2 up to dough stage $\left(\mathrm{I}_{5}\right)$ compared to all other irrigation scheduling treatments (Table 1). This might due to maximum water content in tissue which increases the turgidity and dense proliferation of roots at top layer due to favourable moisture conditions [16]. The lowest root volume $\left(13.7,19.1 \mathrm{cc} \cdot \mathrm{hill}^{-1}\right)$ and root dry weight $\left(2.8,8.3 \mathrm{~g} \cdot \mathrm{hill}^{-1}\right)$ recorded in the treatment of irrigation at IW/CPE of 0.8 throughout the growth stage $\left(\mathrm{I}_{1}\right)$. This was due to increased severity of water stress [17] as water deficit reinforce many 
anatomical changes in the plant, including decrease in cell volume, cell division, cell elongation, intercellular space and thickening of cell wall their by limits the overall root growth.

The application of nitrogen at $150 \mathrm{~kg} \cdot \mathrm{ha}^{-1}$ in 5 equal splits at 20,35, 50, 65 and 80 DAS $\left(\mathrm{N}_{6}\right)$ resulted in the highest root length of $13.5,19.4 \mathrm{~cm}$, root volume of 17.6, $27.6 \mathrm{cc} \cdot \mathrm{hill}^{-1}$ and root dry weight of $6.4,14.4 \mathrm{~g} \cdot \mathrm{hill}^{-1}$ at active tillering and flowering stage respectively (Table 1). The optimum dose and time of nitrogen supply throughout the crop growth period might have increased the root growth as reported by Maheswari et al. [18] and produced more dry matter that could produce additional photosynthates for the development of root system as earlier reported by Devi and Sumathi [19]. Application of nitrogen at $100 \mathrm{~kg} \cdot \mathrm{ha}^{-1}$ in 4 equal splits at 20, 40, 60 and 80 DAS recorded the lowest root length (11.0, 13.6 $\mathrm{cm})$, root volume $\left(13.6,19.9 \mathrm{cc} \cdot \mathrm{hill}^{-1}\right)$ and root dry weight $\left(3.3,8.2 \mathrm{~g} \cdot \mathrm{hill} \mathrm{l}^{-1}\right)$ at active tillering and flowering stage $\left(\mathrm{N}_{1}\right)$. This might due to insufficient supply of nitrogen for better root growth [20].

\section{Interaction Effect (Irrigation $x$ Nitrogen)}

Among the different treatment combinations (Table 2), $\mathrm{I}_{2} \mathrm{~N}_{6}$ i.e., Irrigation at IW/CPE of 0.8 up to panicle initiation stage and thereafter IW/CPE of 1.0 up to

Table 1. Root parameters of aerobic rice as influenced by irrigation scheduling, levels of nitrogen and time of application.

\begin{tabular}{|c|c|c|c|c|c|c|}
\hline \multirow[b]{2}{*}{ Treatments } & \multicolumn{3}{|c|}{ Active tillering stage } & \multicolumn{3}{|c|}{ Flowering stage } \\
\hline & Root length $(\mathrm{cm})$ & $\begin{array}{l}\text { Root volume } \\
\left(\text { cc } \cdot \text { hill }^{-1}\right)\end{array}$ & $\begin{array}{l}\text { Root dry weight } \\
\left(\mathrm{g} \cdot \mathrm{hill}^{-1}\right)\end{array}$ & Root length (cm) & $\begin{array}{l}\text { Root volume } \\
\left(\mathrm{cc} \cdot \text { hill }^{-1}\right)\end{array}$ & $\begin{array}{l}\text { Root dry weight } \\
\left(\mathrm{g} \cdot \mathrm{hill}^{-1}\right)\end{array}$ \\
\hline \multicolumn{7}{|c|}{ Irrigation Scheduling } \\
\hline $\mathrm{I}_{1}$ & 12.6 & 13.7 & 2.8 & 17.9 & 19.1 & 8.3 \\
\hline $\mathrm{I}_{2}$ & 13.0 & 14.6 & 3.3 & 18.8 & 22.0 & 10.1 \\
\hline $\mathrm{I}_{3}$ & 11.8 & 15.0 & 4.4 & 16.5 & 22.9 & 11.2 \\
\hline $\mathrm{I}_{4}$ & 11.6 & 16.1 & 5.7 & 14.2 & 25.3 & 11.8 \\
\hline $\mathrm{I}_{5}$ & 11.1 & 16.9 & 6.1 & 13.5 & 27.1 & 12.9 \\
\hline S.Ed. & 0.23 & 0.55 & 0.08 & 0.35 & 0.56 & 0.20 \\
\hline C.D. $(0.05)$ & 0.53 & 1.27 & 0.19 & 0.80 & 1.29 & 0.46 \\
\hline \multicolumn{7}{|c|}{ Nitrogen Management } \\
\hline $\mathrm{N}_{1}$ & 11.0 & 13.6 & 3.3 & 13.6 & 19.9 & 8.2 \\
\hline $\mathrm{N}_{2}$ & 11.3 & 14.1 & 3.5 & 14.0 & 21.4 & 8.9 \\
\hline $\mathrm{N}_{3}$ & 11.7 & 14.9 & 3.9 & 14.8 & 22.1 & 9.7 \\
\hline $\mathrm{N}_{4}$ & 12.5 & 16.2 & 5.2 & 18.2 & 24.8 & 12.4 \\
\hline $\mathrm{N}_{5}$ & 12.1 & 15.1 & 4.6 & 17.1 & 23.7 & 11.7 \\
\hline $\mathrm{N}_{6}$ & 13.5 & 17.6 & 6.4 & 19.4 & 27.6 & 14.4 \\
\hline S.Ed. & 0.22 & 0.31 & 0.11 & 0.35 & 0.58 & 0.26 \\
\hline C.D. (0.05) & 0.48 & 0.68 & 0.24 & 0.76 & 1.27 & 0.57 \\
\hline
\end{tabular}


Table 2. Interaction ( $\mathrm{x} \mathrm{N}$ ) effect on root parameters of aerobic rice as influenced by irrigation scheduling, levels of nitrogen and time of application.

\begin{tabular}{|c|c|c|c|c|c|c|}
\hline \multirow[b]{2}{*}{ Treatments } & \multicolumn{3}{|c|}{ Active tillering stage } & \multicolumn{3}{|c|}{ Flowering stage } \\
\hline & Root length $(\mathrm{cm})$ & $\begin{array}{l}\text { Root volume } \\
\left(\text { cc } \cdot \text { hill }^{-1}\right)\end{array}$ & $\begin{array}{l}\text { Root dry weight } \\
\quad\left(\mathrm{g} \cdot \mathrm{hill}^{-1}\right)\end{array}$ & Root length $(\mathrm{cm})$ & $\begin{array}{l}\text { Root volume } \\
\quad\left(\mathrm{cc} \cdot \mathrm{hill}^{-1}\right)\end{array}$ & $\begin{array}{l}\text { Root dry weight } \\
\quad\left(\mathrm{g} \cdot \mathrm{hill}^{-1}\right)\end{array}$ \\
\hline $\mathrm{I}_{1} \mathrm{~N}_{1}$ & 11.5 & 12.1 & 1.8 & 14.6 & 18.6 & 6.2 \\
\hline $\mathrm{I}_{1} \mathrm{~N}_{2}$ & 11.2 & 12.6 & 2.0 & 14.9 & 16.5 & 7.1 \\
\hline $\mathrm{I}_{1} \mathrm{~N}_{3}$ & 12.6 & 13.7 & 2.4 & 15.4 & 17.8 & 7.8 \\
\hline $\mathrm{I}_{1} \mathrm{~N}_{4}$ & 13.2 & 14.4 & 3.5 & 21.2 & 19.6 & 8.9 \\
\hline $\mathrm{I}_{1} \mathrm{~N}_{5}$ & 12.7 & 13.8 & 3.1 & 19.5 & 19.2 & 8.1 \\
\hline $\mathrm{I}_{1} \mathrm{~N}_{6}$ & 14.3 & 15.6 & 4.2 & 21.5 & 22.6 & 11.5 \\
\hline $\mathrm{I}_{2} \mathrm{~N}_{1}$ & 11.8 & 13.2 & 2.2 & 15.2 & 19.5 & 7.8 \\
\hline $\mathrm{I}_{2} \mathrm{~N}_{2}$ & 12.1 & 13.7 & 2.5 & 15.5 & 21.1 & 8.2 \\
\hline $\mathrm{I}_{2} \mathrm{~N}_{3}$ & 12.5 & 15.1 & 2.9 & 16.6 & 21.5 & 8.7 \\
\hline $\mathrm{I}_{2} \mathrm{~N}_{4}$ & 13.2 & 15.4 & 3.9 & 21.7 & 22.5 & 11.5 \\
\hline $\mathrm{I}_{2} \mathrm{~N}_{5}$ & 12.9 & 14.2 & 3.4 & 20.2 & 21.7 & 10.6 \\
\hline $\mathrm{I}_{2} \mathrm{~N}_{6}$ & 15.7 & 16.2 & 4.8 & 23.6 & 25.4 & 13.8 \\
\hline $\mathrm{I}_{3} \mathrm{~N}_{1}$ & 10.8 & 13.8 & 2.8 & 13.5 & 20.4 & 8.5 \\
\hline $\mathrm{I}_{3} \mathrm{~N}_{2}$ & 10.9 & 14.1 & 3.1 & 14.2 & 21.6 & 9.2 \\
\hline $\mathrm{I}_{3} \mathrm{~N}_{3}$ & 11.1 & 14.4 & 3.7 & 14.6 & 22.3 & 9.6 \\
\hline $\mathrm{I}_{3} \mathrm{~N}_{4}$ & 12.5 & 16.0 & 5.5 & 18.4 & 23.5 & 12.4 \\
\hline $\mathrm{I}_{3} \mathrm{~N}_{5}$ & 12.0 & 14.8 & 4.5 & 17.6 & 22.6 & 12.2 \\
\hline $\mathrm{I}_{3} \mathrm{~N}_{6}$ & 13.5 & 16.9 & 6.7 & 20.8 & 26.8 & 15.3 \\
\hline $\mathrm{I}_{4} \mathrm{~N}_{1}$ & 10.9 & 14.8 & 4.6 & 12.6 & 19.5 & 8.9 \\
\hline $\mathrm{I}_{4} \mathrm{~N}_{2}$ & 11.2 & 15.1 & 4.9 & 12.8 & 23.1 & 9.6 \\
\hline $\mathrm{I}_{4} \mathrm{~N}_{3}$ & 11.3 & 15.7 & 5.0 & 13.5 & 23.5 & 10.5 \\
\hline $\mathrm{I}_{4} \mathrm{~N}_{4}$ & 11.9 & 16.1 & 6.3 & 15.1 & 28.8 & 13.8 \\
\hline $\mathrm{I}_{4} \mathrm{~N}_{5}$ & 11.7 & 15.8 & 5.7 & 14.8 & 26.3 & 13.4 \\
\hline $\mathrm{I}_{4} \mathrm{~N}_{6}$ & 12.5 & 18.9 & 7.9 & 16.6 & 30.5 & 14.8 \\
\hline $\mathrm{I}_{5} \mathrm{~N}_{1}$ & 10.2 & 14.3 & 4.9 & 12.0 & 21.7 & 9.4 \\
\hline $\mathrm{I}_{5} \mathrm{~N}_{2}$ & 10.9 & 14.9 & 5.1 & 12.6 & 24.8 & 10.2 \\
\hline $\mathrm{I}_{5} \mathrm{~N}_{3}$ & 11.0 & 15.5 & 5.5 & 13.7 & 25.3 & 11.7 \\
\hline $\mathrm{I}_{5} \mathrm{~N}_{4}$ & 11.5 & 19.2 & 6.8 & 14.4 & 29.4 & 15.5 \\
\hline $\mathrm{I}_{5} \mathrm{~N}_{5}$ & 11.3 & 16.9 & 6.2 & 13.5 & 28.6 & 14.2 \\
\hline $\mathrm{I}_{5} \mathrm{~N}_{6}$ & 11.6 & 20.3 & 8.3 & 14.6 & 32.8 & 16.4 \\
\hline S.Ed. & 0.50 & 0.71 & 0.25 & 0.79 & 1.32 & 0.59 \\
\hline C.D. $(0.05)$ & 1.03 & 1.47 & 0.51 & 1.63 & 2.73 & 1.22 \\
\hline
\end{tabular}


dough stage along with $150 \mathrm{~kg} \mathrm{~N} \mathrm{ha}^{-1}$ in 5 equal splits at 20, 35, 50, 65 and 80 DAS significantly enhanced the root length of $15.7 \mathrm{~cm}$ at active tillering and 23.6 $\mathrm{cm}$ at flowering stage. This was due to mild moisture stress and optimum supply of nitrogen throughout the crop growth period was resulted increased root length as earlier reported by Devi and Sumathi [19] and Mahajan et al. [21]. Irrigation at IW/CPE of 1.0 up to panicle initiation stage and thereafter IW/CPE of 1.2 up to dough stage along with application of nitrogen at $150 \mathrm{~kg} \cdot \mathrm{ha}^{-1}$ in 5 equal splits at $20,35,50,65$ and 80 DAS $\left(\mathrm{I}_{5} \mathrm{~N}_{6}\right)$ registered the highest root volume of 20.3, $32.8 \mathrm{cc} \cdot \mathrm{hill}^{-1}$ and root weight of $8.3,16.4 \mathrm{~g} \cdot \mathrm{hill}^{-1}$ at active tillering and flowering stage. This might due to continuous and optimum supply of nitrogen with presence of optimum soil moisture in the root zone throughout the crop growth period as reported earlier by Mandal et al. [22].

\section{Conclusion}

The present investigation reveals that irrigation scheduling with levels and time of nitrogen applications significantly influenced the root throughout the crop growth period. Irrigation scheduling of IW/CPE of 0.8 up to panicle initiation and thereafter IW/CPE of 1.0 up to dough stage along with application of nitrogen at $150 \mathrm{~kg} \cdot \mathrm{ha}^{-1}$ in 5 equal splits at 20,35, 50, 65 and 80 DAS enhanced the root length. Irrigation scheduling of IW/CPE of 1.0 up to panicle initiation stage and thereafter IW/CPE of 1.2 up to dough stage along with application of nitrogen at $150 \mathrm{~kg} \cdot \mathrm{ha}^{-1}$ in 5 equal splits at 20,35, 50, 65 and 80 DAS recorded the highest root volume and root dry weight. The availability of soil moisture with optimum level of nitrogen enhanced the root growth for obtaining higher nutrient uptake and yield of aerobic rice.

\section{Conflicts of Interest}

The authors declare no conflicts of interest regarding the publication of this paper.

\section{References}

[1] United States Department of Agriculture (2016) World Agricultural Production. Foreign Agricultural Service, Circular Series WAP, Washington DC, 7-16.

[2] Dass, A. and Chandra, S. (2013) Irrigation, Spacing and Cultivar Effects on Net Photosynthetic Rate, Dry Matter Partitioning and Productivity of Rice under System of Rice Intensification in Mollisols of Northern India. Experimental Agriculture, 49, 504-523. https://doi.org/10.1017/S0014479713000252

[3] Tuong, T.P. and Bouman, B.A.M. (2003) Rice Production in Water-Scarce Environments. In: Kijne, J.W., Barker, R. and Molden, D., Eds., Water Productivity in Agriculture: Limits and Opportunities for Improvement. CABI Publishing, Wallingford, 53-67.

[4] Xiaoguang, Y., Bouma, B.A.M., Huaqia, W., Zhimin, W., Junfang, Z. and Bin, C. (2005) Performance of Temperate Rice under Different Water Regimes in North China. Agricultural Water Management, 74, 107-112. https://doi.org/10.1016/j.agwat.2004.11.008 
[5] Evans, R.G. and Sadler, E.J. (2008) Methods and Technologies to Improve Efficiency of Water Use. Water Resources Research, 44, 1-15. https://doi.org/10.1029/2007WR006200

[6] Wang, H.Q., Bouman, B.A.M., Zhao, D.L, Wang, C. and Moya, P.F. (2002) Aerobic rice in Northern China: Opportunities and Challenges. In: Bouman, B.A.M., Hengsdijk, H., Hardy, B., Bindraban, P.S., Tuong, T.P., Ladha, J.K., Eds, Water-Wise Rice Production. Proceedings of the International Workshop on Water-Wise Rice Production, 8-11 April 2002. Los Banos, 143-154.

[7] Kato, Y. and Okami, M. (2010) Root Growth Dynamics and Stomatal Behaviour of Rice (Oryza sativa L.) Grown under Aerobic and Flooded Conditions. Field Crops Research, 117, 9-17. https://doi.org/10.1016/j.fcr.2009.12.003

[8] Shi, Q., Zeng, X., Li, M., Tan, X. and Xu, F. (2002) Effects of Different Water Management Practices on Rice Growth. Water-Wise Rice Production, 1, 3-14.

[9] Lampayan, R.M., Bouman, B.A.M., Dios, J.L.D., Espirity, A.J., Soriano, J.B., Lactaoen, A.T., Faronilo, J.E. and Thant, K.M. (2010) Yield of Aerobic Rice in Rainfed Lowlands of the Philippines as Affected by Nitrogen Management and Row Spacing. Field Crops Research, 116, 165-174. https://doi.org/10.1016/j.fcr.2009.12.007

[10] Balasubramanian, R. (2002) Response of Hybrid Rice to Levels and Time of Application of Nitrogen. Indian Journal of Agronomy, 47, 203-204.

[11] Prasad, R. (2011) Aerobic Rice Systems. Advances in Agronomy, 111, 207-246. https://doi.org/10.1016/B978-0-12-387689-8.00003-5

[12] Sathiya, K., Sathyamoorthi, K. and Martin, G.J. (2008) Effect of Nitrogen Levels and Split Doses on the Productivity of Aerobic Rice. Research on Crops, 9, 527-530.

[13] Gomez, K.A. and Gomez, A.A. (1984) Statistical Procedures for Agricultural Research. 2nd Edition, John Wiley and Sons, New York, 680.

[14] Matsuo, N., Ozawa, K. and Mochizuki, T. (2010) Physiological and Morphological Traits Related to Water Use by Three Rice (Oryza sativa L.) Genotypes Grown under Aerobic Rice Systems. Plant Soil, 335, 349-361. https://doi.org/10.1007/s11104-010-0423-1

[15] Parthasarathi, T., Mohandass, S., Senthilvel, S. and Vered, E. (2013) Effects of Impulse Drip Irrigation on Root Response of Aerobic Rice. American-Eurasian Journal of Sustainable Agriculture, 7, 235-240.

[16] Devi, T.G., Zaman, A. and Patra, S.K. (2014) Effect of Irrigation Regimes and Seed Soaking Techniques on Root Growth and Yield of Rice. Journal of Crop and Weed, 10, 320-324.

[17] Gowri, S. (2005) Physiological Studies on Aerobic Rice (Oryza sativa L.). M.Sc. Thesis, Tamil Nadu Agriculture University, Coimbatore.

[18] Maheswari, J., Maragatham, N. and Martin, G.J. (2007) Relatively Simple Irrigation Scheduling and N Application Enhances the Productivity of Aerobic Rice (Oryza sativa L.). American Journal of Plant Physiology, 2, 261-268. https://doi.org/10.3923/ajpp.2007.261.268

[19] Devi, M.G. and Sumathi, V. (2011) Effect of Nitrogen Management on Growth, Yield and Quality of Scented Rice (Oryza sativa L.) under Aerobic Conditions. Journal of Research ANGRAU, 39, 81-83.

[20] Murthy, K.V., Reddy, D.S. and Reddy, G.P. (2012) Response of Rice (Oryza sativa L) Varieties to Graded Levels of Nitrogen under Aerobic Culture. Indian Journal of Agronomy, 57, 367-372.

[21] Mahajan, G., Chauhan, B.S., Timsina, J., Singh, P.P. and Singh, K. (2012) Crop Per- 
formance and Water and Nitrogen-Use Efficiencies in Dry-Seeded Rice in Response to Irrigation and Fertilizer Amounts in Northwest India. Field Crops Research, 134, 59-70. https://doi.org/10.1016/j.fcr.2012.04.011

[22] Mandal, K.G., Kundu, D.K., Thakur, A.K., Kannan, K., Brahmanand, P.S. and Kumar, A. (2013) Aerobic Rice Response to Irrigation Regimes and Fertilizer Nitrogen Rates. Journal of Food, Agriculture and Environment, 11, 1148-1153. 